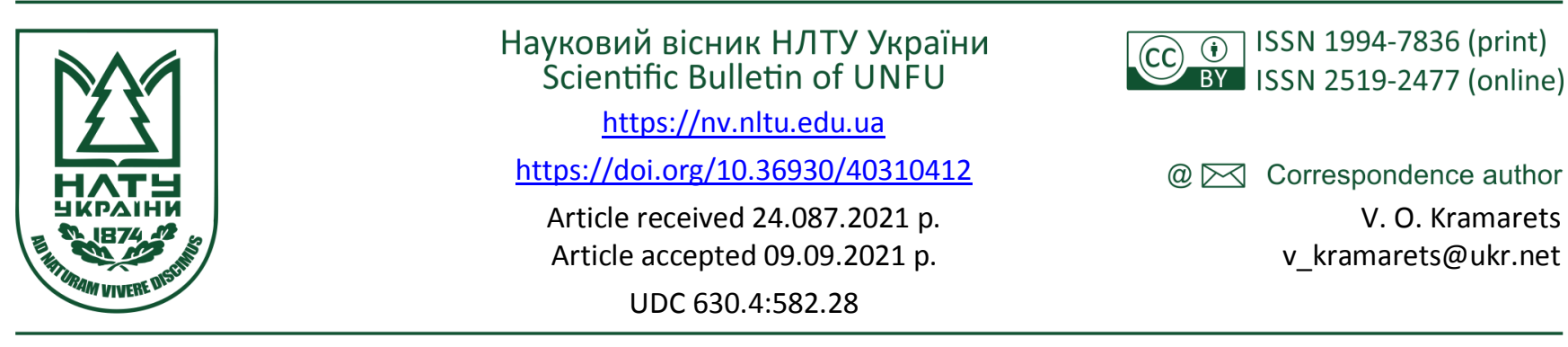

О. Г. Криницька', В. Й. Яхницький', В. О. Крамарець 1

${ }^{I}$ Начіональний лісотехнічний університет України, м. Львів, Украӥна ${ }^{2}$ Страдчівський навчально-виробничий лісокомбінат, смт Івано-Франкове, Украйна

\title{
КСИЛОТРОФНІ МАКРОМЦЕТИ МІШАНИХ ХВОЙНО-ЛИСТЯНИХ ЛІСОСТАНІВ ЛЬВІВСЬКОГО РОЗТОЧЧЯ
}

\begin{abstract}
Досліджено видовий склад ксилотрофних макроміцетів у грабово-сосново-дубових деревостанах (стаціонар кафедри лісівництва: секція I - 120-130-річне материнське насадження і 50-річні лісостани, відтворені природним шляхом після здійснених різних способів поступових рубань - секції II, III, IV) та в сосново-букових, букових і соснових деревостанах Страдчівського навчально-виробничого лісокомбінату. Найбільше різноманіття ксилотрофних макроміцетів виявлено в материнському деревостані. Серед дослідних секцій найбільшу видову різноманітність ксилотрофних грибів виявлено на секції III, де проведена рівномірна поступова двоприйомна рубка, найменшу - на секції II, де проведена рівномірна поступова триприйомна рубка. Однак таксаційні показники деревостанів, відновлених природним шляхом, не вплинули істотно на видовий склад афілофорових грибів. Гірший санітарний стан характерний для материнського деревостану на контрольній секції, що пов'язано із значним віком дерев і проведенням у 2013-2014 pp. на дослідних секціях доглядових рубань низовим методом. Загалом санітарний стан дуба на всіх контрольних секціях є гіршим порівняно із сосною та грабом. Для дерев дуба також встановлено найвищий коефіцієнт ослабленості на усіх дослідних секціях. Інтенсивність процесів диференціації дерев за санітарним станом найвищим $\epsilon$ на контролі, де деревостан уже перейшов у вікову групу - перестиглі. У сосново-букових, чистих букових і соснових деревостанах формується склад ксилотрофних макроміцетів, ідентичний 3 грабово-сосново-дубовими лісостанами. Водночас бук і сосна у чистих деревостанах мають гірші показники санітарного стану, ніж у мішаних лісостанах. У чистих соснових і букових деревостанах вищим $\epsilon$ коефіцієнт інтенсивності процесів диференціації дерев порівняно із мішаними насадженнями. Встановлено зростання кількості дерев із різноманітними патологіями та пошкодженнями в чистих деревостанах бука порівняно із мішаними. У чистих сосняках вищою є кількість дерев із стовбуровими гнилями та плодовими тілами трутовиків. У всіх обстежених мішаних деревостанах переважають макроміцети із екологічної групи сапротрофи на незруйнованій деревині. Серед паразитичних макроміцетів найбільшу небезпеку становлять Fomes $f o-$ mentarius, Laetiporus sulphureus, Ganoderma applanatum, Porodaedalea pini, які є причиною втрати технічної якості деревини.

Ключові слова: грабово-сосново-дубові та сосново-букові деревостани; афілофорові гриби; санітарний стан.
\end{abstract}

\section{Вступ / Introduction}

Територія Українського Розточчя відзначається високопродуктивними мішаними лісостанами - грабоводубово-сосновими, грабово-сосново-дубовими та сосново-буковими, для яких характерні висока біотична стійкість [14] і задовільний санітарний стан $[2,10,17]$. Як фітохвороби, так і комахи-шкідники, зазвичай, розвиваються і поширюються у збалансованому з розвитком інших компонентів лісу ритмі. Водночас несприятливі погодні умови, пошкодження рослин дикими тваринами, масовий розвиток комах-фітофагів та поширення патогенних організмів (зокрема ксилотрофних макроміцетів), пожежі, лісогосподарська і рекреаційна діяльність можуть істотно погіршити життєздатність і біотичну стійкість лісостанів $[8,13,15,17]$.

Об'єкт дослідження - грабово-сосново-дубові та сосново-букові деревостани у сугрудових умовах Львівського Розточчя.
Предмет дослідження - ксилотрофні макроміцети та їх вплив на санітарний стан деревостанів.

Мета роботи - оцінити вплив ксилотрофних макроміцетів на санітарний стан мішаних грабово-сосноводубових і сосново-букових лісостанів Львівського Розточчя.

Для досягнення зазначеної мети визначено таке основне завдання дослідження - визначити видовий склад ксилотрофних макроміцетів і проаналізувати їх вплив на санітарний стан мішаних грабово-сосново-дубових i сосново-букових деревостанів.

Наукова новизна отриманих результатів дослідження - оцінено поширення різних екологічних груп ксилотрофних макроміцетів у грабово-сосново-дубових і сосново-букових деревостанах Львівського Розточчя.

Практична значущість результатів дослідження здійснення аналізу видового складу ксилотрофних макроміцетів дасть змогу запобігти погіршенню якості лі-

\section{Інформація про авторів:}

Криницька Ольга Григорівна, канд. с.-г. наук, ст. наук. співробітник, науково-дослідна частина. Email: Olk-@ukr.net

Яхницький Володимир Йосипович, головний лісничий. Email: snvlk@nltu.edu.ua

Крамарець Володимир Олександрович, д-р с.-г. наук, доцент, кафедра лісівництва. Email: v_kramarets@ukr.net; https://orcid.org/0000-0002-5978-3711

Цитування за ДСтУ: Криницька О. Г., Яхницький В. Й., Крамарець В. О. Ксилотрофні макроміцети мішаних хвойно-листяних лісостанів Львівського Розточчя. Науковий вісник НЛтУ України. 2021, т. 31, № 4. С. 76-81.

Citation APA: Krynytska, O. G., Yakhnytskyi, V. Yo., \& Kramarets, V. O. (2021). Xylorophic macromycetes of mixed conifer-deciduous stands of Lviv Roztocze. Scientific Bulletin of UNFU, 31(4), 76-81. https://doi.org/10.36930/40310412 
соматеріалів внаслідок розвитку патогенів. Водночас наявність грибів-деструкторів опаду та мертвої деревини розглядають як необхідну складову частину лісових екосистем під час ведення наближеного до природи лісового господарства.

Аналіз останніх досліджень та публікацій. Ксилотрофні макроміцети $є$ важливою складовою частиною лісових екосистем. Дослідження цих гетеротрофних організмів, оцінення їх ролі та значення в лісах різних регіонів здійснює чимало дослідників [4, 6, 12, 24]. У природних лісах ксилотрофні макроміцети беруть активну участь у забезпеченні процесів біологічного кругообігу речовин, вони є деструкторами мертвої деревини [4, 22, 24] та є важливим елементом, що забезпечує живлення багатьох організмів-сапрофагів. Однак, в експлуатаційних лісах деякі види трутових грибів (збудники кореневих і стовбурових гнилей деревних порід) можуть бути причиною значних втрат ділової деревини [24, 25].

Дослідження ксилотрофних макроміцетів на теритоpiї Українського Розточчя (зокрема, Львівського Розточчя) мали епізодичний характер та більше стосувалися їх видового складу $[2,18,19,25]$. Потребує грунтовнішого дослідження вплив цієї групи грибів на функціонування насаджень, зокрема мішаних хвойно-листяних лісостанів.

Матеріали та методи дослідження. Дослідження видового складу ксилотрофних базидіоміцетів грабовососново-дубових лісостанів виконували на науково-виробничому стаціонарі, закладеному під керівництвом проф. М. М. Горшеніна [5]. Об'єктами стаціонарних досліджень були 120-130-річне материнське насадження (секція I, 6Сз3Дз1Гз + Бкл, Лпд, Бб, Клг) і 50-річні грабово-сосново-дубові деревостани, відтворені природним шляхом після проведення різних способів поступових рубок (секції II, 7Дз1Сз1Гз1КлгБкл + Дч, Мдє, Лпд, Ябл; III, 8Сз1Дз1БклГз + Яв, Клг, Ялє, Дч; IV, $7 Д 32 \mathrm{C}_{3} 1 Г з+$ Бк, Дч, Чш, Клг, Яв, Бб, Лпд) [9]. На секції II проведена триприйомна рівномірна поступова рубка,
III - двоприйомна рівномірна поступова рубка, IV триприйомна групово-вибіркова рубка.

Для вивчення видового складу афілофорових грибів сосново-букових лісів заклали пробні площі у мішаному сосново-букововому (ПП-1, 7Сз3Бкл), буковому (ПП-2, 10Бкл + Сз) та сосновому (ПП-3, 10С3 + Бкл, Гз) деревостанах віком 120-130 років, сформованих у Великопільському та Страдчівському лісництвах Страдчівського навчально-виробничого лісокомбінату Національного лісотехнічного університету України.

Під час обстеження дерева розподіляли за категоріями санітарного стану [16]. Для оцінювання стану обстежених деревостанів розраховували середньозважений індекс санітарного стану дерев [7], середньозважений індекс санітарного стану живих дерев (I-IV категорій санітарного стану), коефіцієнт інтенсивності процесів диференціації дерев у насадженнях (частка дерев I категорії санітарного стану), коефіцієнт ослабленості (співвідношення часток здорових і ослаблених дерев), коефіцієнт стабільності (співвідношення часток здорових і сильно ослаблених дерев), що запропонували В. В. Степанчик із співавторами [20, 21].

Видовий склад ксилотрофних макроміцетів визначали за допомогою спеціальної літератури та інтернет-ресурсів [3, 23]. Назви грибів уточнювали за інтернет-ресурсом http://www.speciesfungorum.org/Names/Names.asp. Виявлені в деревостанах ксилотрофні макроміцети належали до різних екологічних груп: сапротрофи на незруйнованій деревині (Lei - lignum epigaeum integrum); сапротрофи на зруйнованій деревині (Lep - lignum epigaeum putridum); сапротрофи на зануреній у грунт деревині $(L h$ - lignum hypogaeum); паразити $(P$ - parasiti) $[1,6]$.

\section{Результати дослідження та їх обговорення / Research results and their discussion}

Грабово-сосново-дубові деревостани. На стаціонарних секціях грабово-сосново-дубових деревостанів виявлено 26 видів ксилотрофних грибів, які належать до різних екологічних груп (табл. 1).

Табл. 1. Видовий склад ксилотрофних грибів / Species composition of xylotrophic fungi

\begin{tabular}{|c|c|c|c|c|c|c|c|c|c|c|}
\hline \multirow{2}{*}{$\begin{array}{l}\text { № } \\
\text { 3/ח }\end{array}$} & \multirow[t]{2}{*}{ Вид гриба } & \multirow{2}{*}{$\begin{array}{c}\text { Екологіч- } \\
\text { на група } \\
\text { грибів }\end{array}$} & \multicolumn{4}{|c|}{$\begin{array}{l}\text { Грабово-сосново-дубові лі- } \\
\text { состани (секції стаціонару) }\end{array}$} & \multicolumn{3}{|c|}{$\begin{array}{l}\text { Сосново-букові дере- } \\
\text { востани (пробні площі) }\end{array}$} & \multirow{2}{*}{ Порода дерев- } \\
\hline & & & I & II & III & IV & ПП-1 & ПП-2 & ПП-3 & \\
\hline 1 & 2 & 3 & 4 & 5 & 6 & 7 & 8 & 9 & 10 & 11 \\
\hline 1 & $\begin{array}{l}\text { Б'єркандера обвуглена Bjerkandera adusta } \\
\text { (Willd.) P. Karst. }\end{array}$ & Lei & + & & + & & + & + & & Дз, Бкл, Гз \\
\hline 2 & $\begin{array}{l}\text { Вюллемінія з'їдаюча Vuilleminia comedens } \\
\text { (Nees) Maire }\end{array}$ & Lei & + & + & + & + & & & & Дз \\
\hline 3 & $\begin{array}{l}\text { Губка березова Piptoporus betulinus (Bull.: } \\
\text { Fr.) P. Karst. }\end{array}$ & Lei, $\mathrm{P}$ & & & & + & & & & Бб \\
\hline 4 & Губка дубова Daedalea quercina L.: Fr. & Lei & + & & & & & & & Дз \\
\hline 5 & $\begin{array}{l}\text { Губка соснова Porodaedalea pini (Brot.) } \\
\text { Murrill }\end{array}$ & $P$ & & & & + & + & + & & $\mathrm{C}_{3}$ \\
\hline 6 & Їжовик жовтуватий Hydnum repandum L.: Fr. & $\mathrm{Lh}$ & + & & & + & + & + & & $\begin{array}{l}\text { деревина в } \\
\text { грунті }\end{array}$ \\
\hline 7 & $\begin{array}{l}\text { Ксиларія поліморфна Xylaria polymorpha } \\
\text { (Pers.) Grev. }\end{array}$ & Lep & + & + & + & & + & + & & Д3, Гз \\
\hline 8 & Опеньок осінній Armillaria mellea s.1. & P, Lei & + & + & + & + & + & + & + & Дз, Бкл, С3, Гз \\
\hline 9 & Рамарія жовта Ramaria flava (Schaeff.) Quél. & Lh & + & + & & + & + & + & & \begin{tabular}{|c|} 
деревина в \\
грунті \\
\end{tabular} \\
\hline 10 & $\begin{array}{l}\text { Стереум шерстистий Stereum hirsutum } \\
\text { (Willd.) Pers. }\end{array}$ & Lei, $\mathrm{P}$ & + & & + & + & + & + & & Бкл, Гз, Бб \\
\hline 11 & $\begin{array}{l}\text { Стовповий гриб Gloeophyllum sepiarium } \\
\text { (Wulfen) P. Karst. }\end{array}$ & Lei & + & + & + & + & + & & + & $\mathrm{C} 3$ \\
\hline 12 & $\begin{array}{l}\text { Траметес жорстковолосистий Trametes hir- } \\
\text { suta (Wulfen) Lloyd }\end{array}$ & Lei & + & & + & + & + & + & & Дз, Бкл, Гз, Бб \\
\hline
\end{tabular}




\begin{tabular}{|c|c|c|c|c|c|c|c|c|c|c|}
\hline 1 & 2 & 3 & 4 & 5 & 6 & 7 & 8 & 9 & 10 & 11 \\
\hline 13 & $\begin{array}{l}\text { Tраметес охряний Trametes ochracea (Pers.) } \\
\text { Gilb. \& Ryvarden }\end{array}$ & Lei & & & + & & + & + & & Дз, Бкл, Гз \\
\hline 14 & $\begin{array}{l}\text { Tраметес різнобарвний Trametes versicolor } \\
\text { (L.) Lloyd }\end{array}$ & Lei & & + & + & & + & + & & Дз, Бкл, Гз \\
\hline 15 & $\begin{array}{l}\text { Тріхаптум буро-фіолетовий Trichaptum fus- } \\
\text { coviolaceum (Ehrenb.) Ryvarden) }\end{array}$ & Lei & & & & & + & & + & C3 \\
\hline 16 & $\begin{array}{l}\text { Трутовик березовий пластинчастий Lenzites } \\
\text { betulinus (L.) Fr. }\end{array}$ & Lei & + & & & + & & & & Гз, Бб \\
\hline 17 & $\begin{array}{l}\text { Трутовик бугристий Daedaleopsis confrago- } \\
\text { sa (Bolton) J. Schröt. }\end{array}$ & Lei & & & + & & + & + & & Бкл, Гз, Клг \\
\hline 18 & Трутовик горбатий Trametes gibbosa (Pers.) Fr. & Lei & + & & + & & + & & & Дз, Бкл, Гз, Клг \\
\hline 19 & $\begin{array}{l}\text { Tрутовик несправжній Phellinus igniarius } \\
\text { (L.) Quél. }\end{array}$ & $\mathrm{P}$ & + & & + & & & & & $\Gamma 3$ \\
\hline 20 & $\begin{array}{l}\text { Трутовик несправжній дубовий Phellinus } \\
\text { robustus (P. Karst.) Bourdot et Galzin }\end{array}$ & $\mathrm{P}$ & + & & & & & & & Дз \\
\hline 21 & $\begin{array}{l}\text { Трутовик облямований Fomitopsis pinicola } \\
\text { (Sw.: Fr.) P. Karst }\end{array}$ & Lei & + & + & + & + & + & & + & Сз, Гз, Бб \\
\hline 22 & $\begin{array}{l}\text { Трутовик плоский Ganoderma applanatum } \\
\text { (Pers.) Pat. }\end{array}$ & Lei, $\mathrm{P}$ & + & + & & + & + & + & & Дз, Гз, Бб \\
\hline 23 & $\begin{array}{l}\text { Трутовик сірчано-жовтий Laetiporus sulphu- } \\
\text { reus (Bull.) Murrill }\end{array}$ & $\mathrm{P}$ & + & & & & + & & & Дз, Бкл \\
\hline 24 & Трутовик справжній Fomes fomentarius (L.) Fr. & P, Lei & + & & + & + & + & + & & Бкл, Гз, Бб \\
\hline 25 & $\begin{array}{l}\text { Трясучка листувата Phaeotremella foli- } \\
\text { acea (Pers.) Wedin, J.C. Zamora \& Millanes }\end{array}$ & Lep & + & & & + & + & & & $\begin{array}{l}\text { Мертві дерева } \\
\text { листяних порід }\end{array}$ \\
\hline 26 & Шизофіл звичайний Schizophyllum commune Fr. & Lei, $\mathrm{P}$ & + & + & + & + & + & + & & Дз, Бкл, Клг, Бб \\
\hline
\end{tabular}

Примітки: Екологічні групи грибів: Lei - сапротрофи на незруйнованій деревині; Lep - сапротрофи на зруйнованій деревині; Lh - сапротрофи на деревині, присипаній грунтом; P - паразити;

Породи дерев: Бб - береза бородавчаста; Бкл - бук лісовий; Гз - граб звичайний; Дз - дуб звичайний; Клг - клен гостролистий, Сз - сосна звичайна.

Загалом в обстежених деревостанах формується видовий склад грибів, властивих для мішаних лісів Розточчя. Здебільшого у грабово-сосново-дубових деревостанах усіх дослідних секцій стаціонару поширена екологічна група грибів - сапротрофи на незруйнованій деревині (всього 18 видів). Але зрідка трапляються представники інших екологічних груп - сапротрофи на зруйнованій деревині (2 види), сапротрофи на присипаній грунтом деревині (2 види) і паразити (4 види). Шість видів сапротрофів на незруйнованій деревині $\epsilon$ одночасно і паразитами. Більшу видову різноманітність ксилотрофних макроміцетів виявлено на секції I, де росте материнський деревостан 120-130-річного віку (19 видів). Серед дослідних секцій (50-річні деревостани природного походження) найбільшу видову різноманітність ксилотрофних макроміцетів встановлено на секції III, де проведена рівномірна поступова двоприйомна рубка (15 видів), найменшу на секції II - проведена рівномірна поступова триприйомна рубка (9 видів). На секції IV, де проведена групово-вибіркова триприйомна рубка, обліковано 14 видів фітопатогенних грибів.

Загалом гірший санітарний стан характерний для материнського деревостану на секції I, ніж на дослідних секціях, де формуються молоді деревостани (рис. 1). Це пов'язано із значним віком материнських дерев на контролі і проведенням у 2013-2014 pp. на дослідних секціях доглядових рубань. Рубки на цих секціях проведені низовим методом, при цьому вирубували відсталі в рості, хворі та пошкоджені дерева, що позитивно вплинуло на санітарний стан молодих деревостанів. Кращий санітарний стан на усіх секціях характерний для дерев сосни порівняно з деревами дуба і добрий - для дерев граба, який витримує значне затінення. Середні категорії санітарного стану дерев на секціях стаціонару є досить близькими (практично однаковими) - проведені доглядові рубання на дослідних секціях позитивно вплинули на стан дерев.
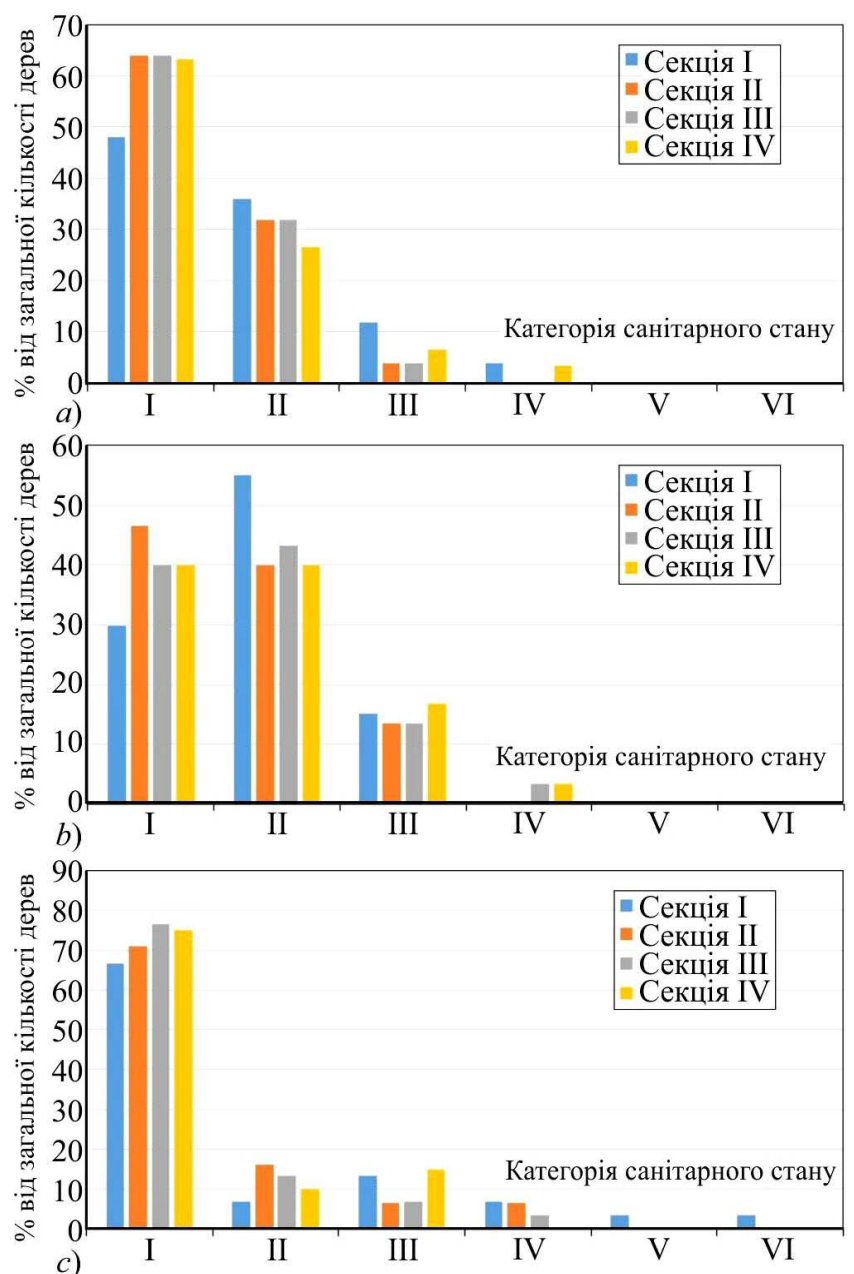

Рис. 1. Розподіл дерев за категоріями санітарного стану на секціях стаціонару / Distribution of trees by categories of sanitary condition in sections of the trial areas: $a$ ) - сосна / pine; $b$ ) дуб / oak, c) - граб / hornbeam 
Показник середньої категорії санітарного стану дерев на них, на відміну від материнського деревостану, має нижчі значення (близькі до 1), що свідчить про задовільний стан дерев. Коефіцієнт інтенсивності процесів диференціації дерев за санітарним станом найвищим є на контролі, де деревостан уже перейшов у вікову групу - перестиглі. Дослідні секції за цим показником характеризуються нижчими величинами і $є$ близькими між собою (відмінності між ними неістотні). Водночас на усіх секціях коефіцієнт інтенсивності процесів диференціації дерев є вищим для дуба (табл. 2).

Значення коефіцієнта ослабленості деревостану (співвідношення частки здорових і ослаблених дерев) на контролі (материнський деревостан) є значно вищим, ніж на секціях. Істотної різниці між дослідними секціями за цим показником не виявлено. Серед деревних порід найвищий коефіцієнт ослабленості на усіх секціях характерний для дуба. На контролі для сосни він становить 0,75 , дуба - 1,83, граба - тільки 0,10 ; на дослідних секціях коливається в межах: для сосни - 0,42-0,50, дуба - 0,86-1,00 і граба - 0,13-0,23. Водночас треба відзначити, що на всіх секціях стаціонару для всіх порід коефіцієнти ослабленості є низькими, що свідчить про задовільний фітопатологічний стан деревостанів стаціонару (табл. 2).

Коефіцієнти стабільності дерев сосни (співвідношення частки здорових і сильно ослаблених дерев) на дослідних секціях стаціонару мають значення 0,06-0,10, на контролі значення цих коефіцієнтів для сосни в 2,03,5 рази вищі. Коефіцієнти стабільності дерев дуба на дослідних секціях стаціонару становлять 0,22-0,31 i є близькими до таких значень на контролі та вищими, ніж у сосни і граба.

Сосново-букові деревостани. видовий склад ксилотрофних макроміцетів у сосново-букових деревостанах показано в табл. 1, а показники санітарного стану сосново-букових деревостанів наведено в табл. 3.

Згідно 3 даними табл. 1, видовий склад ксилотрофних грибів у сосново-букових деревостанах є близьким до складу ксилотрофних макроміцетів у грабово-сосново-дубових лісостанах. Найпоширенішою в цих деревостанах також $є$ екологічна група грибів - сапротрофи на незруйнованій деревині (14 видів) і значно менше виявлено сапротрофів на зруйнованій деревині (2 види).

Треба зазначити, що показник середньої категорії санітарного стану дерев сосни у сосново-букових деревостанах, порівняно з грабово-сосново-дубовими, $\epsilon$ вищим (1,2 раза), а показники середньої категорії санітарного стану сиророслих дерев (1,1 раза), коефіцієнт інтенсивності процесів диференціації дерев (1,2 раза), коефіцієнт ослабленості (2,6 раза) і коефіцієнт стабільності (1,2 раза) - нижчими (див. табл. 3). Отже, дерева сосни у сосново-букових деревостанах відзначаються життєвим станом.

Табл. 2. Показники санітарного стану дерев на секціях стаціонару в грабово-сосново-дубових лісостанах / Indicators of the sanitary condition of trees in sections of the trial areas in hornbeam-pine-oak forests

\begin{tabular}{|c|c|c|c|c|c|c|c|c|c|c|c|c|}
\hline \multirow{3}{*}{ Показник } & \multicolumn{12}{|c|}{ Секції } \\
\hline & \multicolumn{3}{|c|}{ I } & \multicolumn{3}{|c|}{ II } & \multicolumn{3}{|c|}{ III } & \multicolumn{3}{|c|}{ IV } \\
\hline & сосна & дуб & граб & сосна & дуб & граб & сосна & дуб & граб & сосна & дуб & граб \\
\hline Середня категорія санітарного стану дерев & 1,72 & 1,85 & 1,83 & 1,40 & 1,67 & 1,48 & 1,40 & 1,80 & 1,37 & 1,50 & 1,83 & 1,40 \\
\hline Середня категорія стану сиророслих дерев & 1,72 & 1,85 & 1,57 & 1,40 & 1,67 & 1,48 & 1,40 & 1,80 & 1,37 & 1,50 & 1,83 & 1,40 \\
\hline $\begin{array}{l}\text { Коефіцієнт інтенсивності процесів дифе- } \\
\text { ренціації дерев }\end{array}$ & 2,08 & 3,33 & 1,50 & 1,56 & 2,14 & 1,41 & 1,56 & 2,50 & 1,30 & 1,58 & 2,50 & 1,33 \\
\hline Коефіцієнт ослабленості & 0,75 & 1,83 & 0,10 & 0,50 & 0,86 & 0,23 & 0,50 & 1,08 & 0,17 & 0,42 & 1,00 & 0,13 \\
\hline Коефіцієнт стабільності & 0,21 & 0,28 & 0,24 & 0,06 & 0,22 & 0,10 & 0,06 & 0,24 & 0,09 & 0,10 & 0,31 & 0,21 \\
\hline
\end{tabular}

Табл. 3. Показники санітарного стану дерев на секціях стаціонару в сосново-букових лісостанах / Indicators of sanitary condition of trees in sections of the trial areas in pine-beech stands

\begin{tabular}{|c|c|c|c|c|}
\hline Показники & \multicolumn{2}{|c|}{ ПП-1 } & \multicolumn{1}{|c|}{ ПП-2 } & \multicolumn{2}{c|}{ бП-3 } \\
\cline { 2 - 6 } & сосна & бук & бук & сосна \\
\hline Середня категорія санітарного стану дерев & 2,00 & 1,54 & 2,01 & 2,44 \\
\hline Середня категорія стану сиророслих дерев & 1,56 & 1,48 & 1,89 & 1,90 \\
\hline Коефіцієнт інтенсивності процесів диференціації дерев & 1,71 & 1,48 & 2,29 & 2,72 \\
\hline Коефіцієнт ослабленості & 0,29 & 0,23 & 0,62 & 0,78 \\
\hline Коефіцієнт стабільності & 0,17 & 0,21 & 0,38 & 0,30 \\
\hline
\end{tabular}

Водночас і бук, і сосна у чистих деревостанах мають гірші показники санітарного стану. Найбільш істотною $\epsilon$ різниця коефіцієнтів ослабленості дерев - у чистих сосняках цей показник у 2,6, а в чистих букових деревостанах у 3,5 раза є вищим порівняно із мішаним сосново-буковим лісостаном. Вищим у чистих соснових i букових деревостанах $є$ коефіцієнт інтенсивності процесів диференціації дерев (частка дерев I категорії санітарного стану від їх загальної кількості на пробній площі). У чистих деревостанах зменшується кількість здорових дерев (I категорії санітарного стану) і зростає кількість ослаблених дерев (рис. 2). Встановлено також зростання кількості дерев із різноманітними патологіями та пошкодженнями в чистих деревостанах бука порівняно із мішаними (рис. 3).

Зокрема, кількість дерев бука із ознаками ураження стовбуровими гнилями збільшується від 11,9 до 17,7 \%,
3 плодовими тілами трутовиків - від 5,1 до 12,5 \%. Вищим є ступінь пошкодження бука морозобійними тріщинами та механічними пошкодженнями. Кількість дерев бука із раковими виразками та ранами в чистих букових деревостанах $є$ більшою у 6,1 раза (збільшується від 3,4 до 20,8 \%). У чистих соснових насадженнях також значно вищою $є$ кількість дерев із стовбуровими гнилями та плодовими тілами трутовиків - відповідно у 2,2 та 4,7 раза.

Обговорення результатів дослідження. Ксилотрофні макроміцети в обстежених деревостанах Львівського Розточчя $\epsilon$ невід'ємною складовою частиною лісових екосистем, що узгоджується із дослідженнями, здійсненими в інших регіонах $[6,22]$. Ця група гетеротрофних організмів бере участь у процесах деструкції мертвої деревини та забезпечує перебіг процесів кругообігу речовин. 

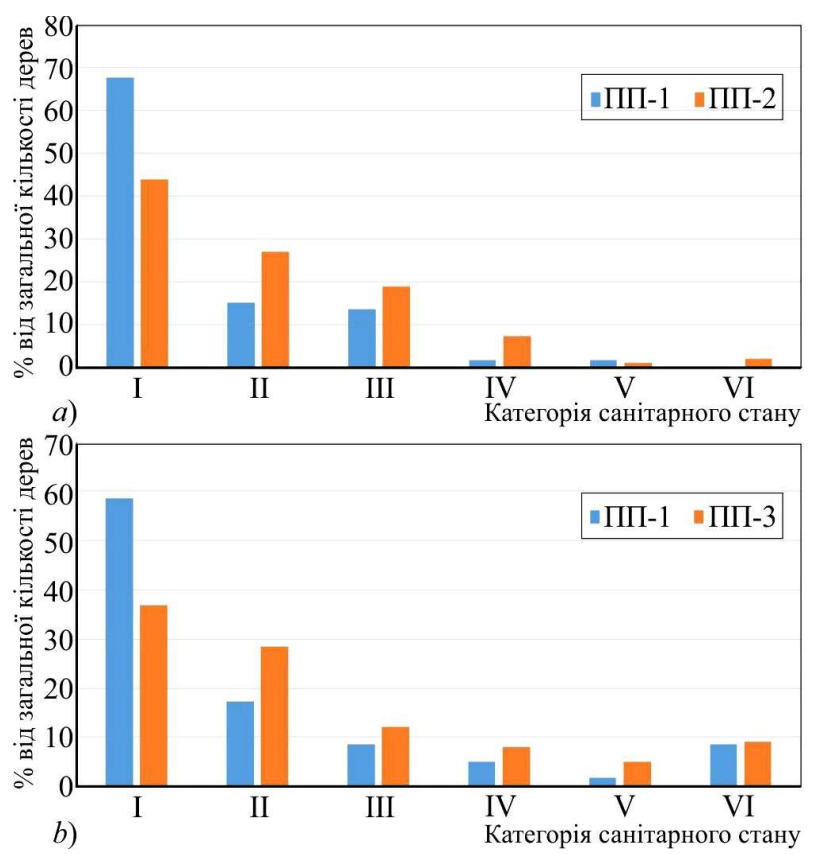

Рис. 2. Розподіл дерев за категоріями санітарного стану в сосново-букових деревостанах / Distribution of trees by categories of sanitary condition in pine-beech stands: $a$ ) бук / beech; $b$ ) сосна / pine
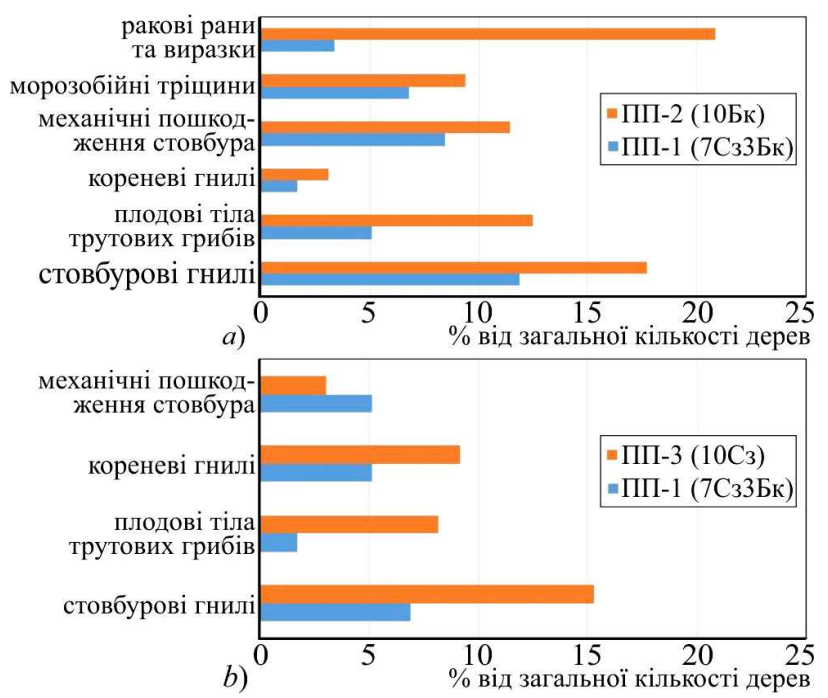

Рис. 3. Кількість дерев із ознаками хвороб та пошкоджень /

Number of trees with signs of disease and damage, \%: $\%$ ) бук / beech; $b$ ) сосна / pine

У грабово-сосново-дубових деревостанах загалом істотного ураження патогенними грибами-ксилотрофами дерев сосни, дуба і граба на усіх секціях стаціонару не виявлено. Навіть досить небезпечний для лісових насаджень Львівського Розточчя опеньок осінній (Arlmillaria mellea L.) розвивається переважно на сильно ослаблених деревах, пришвидшуючи їх відмирання. Небезпечними паразитами дуба $є$ сірчано-жовтий, несправжній дубовий та плоский трутовики, які поширені в деревостані на контрольній секції у старовіковому материнському деревостані. Більш життєздатними, біотично стійкішими є молоді деревостани на дослідних секціях, ніж материнський деревостан на контролі. Причому проведені на дослідних секціях окремі способи поступових рубок головного користування (рівномірна поступова двоприйомна, рівномірна поступова триприйомна, групово-вибіркова триприйомна) не мають достовірно відмітного впливу на біотичну стійкість грабово-дубово-соснових (секція III) та грабово-дубо- вих 3 домішкою сосни (секції II і IV) деревостанів, відновлених природним насіннєвим шляхом, а також на розвиток у них ксилотрофних макроміцетів. Забезпечення відтворення деревостанів, близьких за складом до корінних для едафо-кліматичних умов Львівського Розточчя, на основі природного поновлення $є$ одним із напрямків ведення наближеного до природи лісового господарства [11].

Основним збудником стовбурових гнилей у букових лісостанах є справжній трутовик, а в сосняках - соснова губка. За даними Цилюрика А. В, Шевченка С. В. [24] саме ці гриби $є$ основними причинами різкого зниження виходу ділової деревини у старовікових деревостанах бука та сосни. Водночас можна відзначити, що в мішаному сосново-буковому деревостані санітарний стан дерев $\epsilon$ кращим порівняно із чистими деревостанами цих порід.

Дослідження в лісостанах різних порід показують збільшення ролі та значення грибів-збудників стовбурових гнилей у деревостанах старшого віку $[8,25]$. Нагромадження значних запасів деревини запускає природний механізм утилізації та перетворення нагромадженої органічної маси та після відмирання дерев і діяльності сапротрофних організмів містить в процеси кругообігу речовин [22]. В обстежених лісостанах ксилотрофні гриби призводять до поступового та тривалого процесу погіршення стану дерев, але не спричиняють їх масового та інтенсивного всихання.

\section{Висновки / Conclusions}

Загалом як грабово-сосново-дубові, так і сосновобукові деревостани Львівського Розточчя відзначаються задовільним станом і характеризуються формуванням видового складу ксилотрофних макроміцетів, які належать до різних екологічних груп: сапротрофи на незруйнованій деревині, сапротрофи на зруйнованій деревині, сапротрофи на присипаній грунтом деревині i паразити. Поступові рубки головного користування (рівномірна поступова двоприйомна, рівномірна поступова триприйомна і групово-вибіркова триприйомна) практично однаково (статично достовірної різниці немає) впливають на розвиток фітопатогенних грибів і біотичну стійкість грабово-сосново-дубових деревостанів, відновлених природним насіннєвим шляхом.

Для чистих деревостанів сосни та бука характерні більша кількість дерев із стовбуровими гнилями та гірший санітарний стан.

\section{References}

1. Astapenko, V. V. (1990). Consortium ties of wood-destroying mushrooms in the middle Priangarye. Mycology and Phytopathology, 24(4), 289-298. [In Russian].

2. Bazyuk-Dubey, I. V. (2012). Ecological analysis micoflory Ukrainian Roztochya. Scientific Bulletin of UNFU, 22(2), 43-48. Retrieved from: http://nbuv.gov.ua/UJRN/nvnltu $2012 \quad 22.2 \quad 10$

3. Bondartseva, M. A., \& Parmisto, E. Kh. (1986). Keys to mushrooms of the USSR. The order of Aphyllophorales. Leningrad: Science. [In Russian].

4. Dudka, I. (2003). Macromycetes of the Ukrainian Carpathians, species diversity and protection. Proceedings of the Shevchenko scientific society: Ecological collection. Ecological problems of Carpathian Region, XII, 171-182. Retrieved from: http://dspace.nbuv.gov.ua/handle/123456789/73582

5. Horshenin, M. M. (1972). Stationary studies of the influence of different methods of gradual felling on environmental conditions, productivity of stands and reforestation. Forestry research in Roztocze. Lviv: Kameniar, 14-24. [In Ukrainian]. 
6. Ivanenko, O. M. (2012). Consorts connection of populations aphyllophoroid fungi of the Kyivske Plato. Optimization and Protection of Ecosystems, 7, 167-178. Retrieved from: http://nbuv.gov.ua/UJRN/ecooo 2012721 under the influence of industrial emissions. Ecology and forest protection, 6, 39-43. [In Russian].

8. Kramarets, V. O., \& Matsiakh, I. P. (2018). The role of biotic factors in spruce decline in the Ukrainian Carpathians. Proceedings of the forestry academy of sciences of Ukraine, 17, 121-132. https://doi.org/10.15421/411827

9. Krynttska, O. G. (2019). Forest-ecological principles of natural regeneration and formation of pine-oak forests in the conditions of the Lviv Roztochya: dissertation for earning $\mathrm{PhD}$ in agricultural sciences, specialty (06.03.03 - Forest Science and Forestry). Kharkiv, 22 p. Retrieved from: https://uriffm.org.ua/media/dissertation/aref $0 . p d f$

10. Krynytska, O. G. (2015). Influence of different methods of gradual felling on productivity and phytopathological condition of hornbeam-pine-oak stands of natural origin in the conditions of Lviv Roztocze. Abstracts of the reports of the International scientific-practical conference "Challenges of the XXI century and their solution in the forest complex and environment. Kyiv, 61-62. [In Ukrainian].

11. Krynytskyi, H. T., Chernyavskyi, M. V., Krynytska, O. H., Deineka, A. M., Kolisnyk, B. I., \& Tselen, Ya. P. (2017). Close-to-nature forestry as the basis for sustainable forest management in Ukraine. Scientific Bulletin of UNFU, 27(8), 26-31. https://doi.org/10.15421/40270803

12. Maksymchuk, N. V. (2013). Biological features of the spread of stem rot pathogens in oak plantations (on the example of DP "Bereznivske LH"). Scientific Herald of NULES of Ukraine. Series: Forestry and Decorative Gardening, 187(1), 266-271. Retrieved from: http://nbuv.gov.ua/UJRN/nvnau lis $2013 \quad 187 \quad 144$

13. Meshkova, V. L. (2011). Dynamics of sanitary condition of oak stands in the left-bank Forest Steppe of Ukraine after forest management operations. Forestry Journal, 1, 28-32. Retrieved from: http://dspace.nbuv.gov.ua/handle/123456789/38840

14. Myklush, Y., Myklush, S., Havryliuk, S., \& Savchyn, V. (2021). Main forestry and management indices of pine (Pinus sylvestris L.) stands involving beech (Fagus sylvatica L.) in composition of Ukrainian Roztochchia. Folia Forestalia Polonica, Series A - Forestry, 2, 81-87. https://doi.org/10.2478/ffp-2021-0009
7. Karpenko, A. D. (1981). Assessment of the state of forest stands

15. Osypenko, N. I. (1972). Entomocomplexes of trunk pests of coniferous species at different types of tree death in the conditions of Ivano-Frankivsk educational and production forestry. Forestry research in Roztocze. Lviv, Kamenyar, 275-278. [In Ukrainian].

16. Sanitary rules in the forests of Ukraine. (2020). Retrieved from: https://zakon.rada.gov.ua/laws/show/756-2016-\%D0\%BF\#Text

17. Shevchenko, S. V. (1972). Features of growth of pine crops affected by shutte and twisting rust of pines. Forestry research in Roztocze. Lviv, Kamenyar, 267-274. [In Ukrainian].

18. Stasevytch, L. I. \& Kharambura, Ya. J. (1996). Diseases and insect pests of Roztocze forest species. Scientific Bulletin of UkrDLTU, 5, 175-178. [In Ukrainian].

19. Stasevytch, L., \& Kharambura, Ya. (2003). Diseases and phytophagous insects of the pine-tree (Pinus silvestris L.) in the Western region of Ukraine. Visnyk of Lviv university: Biology Series, 33, 42-46. Retrieved from: http://prima.lnu.edu.ua/faculty/biologh/wis/33/botanics/05/05.pdf

20. Stepanchik, V. V. (2010). Methodological approaches to assessing the sustainability of pine stands. Forest science of the XXI century: materials of the international scientific-practical conference dedicated to the 80th anniversary of the Forest Institute of the National Academy of Sciences of Belarus. Gomel: Forest Institute of the National Academy of Sciences of Belarus, 484 487. [In Russian].

21. Stepanchik, V. V., Vasilenko, A. I., \& Savluk, S. V. (2010). Vitality structure of pine culture cenoses in the system for assessing their sustainability. Problems of forestry: collection of scientific articles. Gomel: Forest Institute of the National Academy of Sciences of Belarus, 70, 514-525. [In Russian].

22. Storozhenko, V. G. (2017). Fungal biotrophic wood-destroying biota in forest ecosystems of European Russia. Ulyanovsk Medico-biological Journal, 1, 147-154. Retrieved from: https://elibrary.ru/item.asp?id $=28927230$

23. Svetlova, T. V., \& Zmitrovich, I. V. (2018). Polypores and other wood-dwelling Aphyllophorales fungi. Retrieved from: http://mycoweb-stv.ru/aphyllophorales/index.html

24. Tatarynova, O. K. (2003). Xylotrophic basidiomycetes of Olevsk physico-geographical region of Zhytomyrske Polissia. Scientific principles of biodiversity conservation, 5, 182-186. Retrieved from: http://www.ecoinst.org.ua/b5-2003/rs33.pdf

25. Tsyliuryk, A. V., \& Shevchenko, S. V. (2008). Forest phytopathology. Kyiv: KVIC. [In Ukrainian].

\section{O. G. Krynytska1, V. Yo. Yakhnytskyi², V. O. Kramarets ${ }^{1}$}

${ }^{I}$ Ukrainian National Forestry University, Lviv, Ukraine

${ }^{2}$ Stradch Training and Production Forestry Enterprise, Ivano-Frankove, Ukraine

\section{XYLOROPHIC MACROMYCETES OF MIXED CONIFER-DECIDUOUS STANDS OF LVIV ROZTOCZE}

The study of the xylotrophic macromycetes species composition was carried out in hornbeam-pine-oak stands (research station of Forestry Department: section I - 120-130-year-old mother plantation and 50-year-old tree stands, reproduced naturally after various methods of gradual felling, section III, section II) and in pine-beech, beech and pine stands of Stradch Educational and Research Forestry Station. The greatest variety of xylotrophic macromycetes was found in the mother forest stand. Among the experimental sections, the largest species diversity of xylotrophic fungi was detected in section III in the area with implemented a uniform gradual two-reception felling, and the smallest xylotrophic fungi diversity was observed on the research in section II with a uniform gradual three-reception felling done in the past. However, the taxonomic parameters of naturally restored stands did not significantly affect the species composition of aphyllophorales fungi. Due to the age of the trees and felling care by the grassroots method conducted in 2013-2014 on the experimental sections the worst sanitary condition was observed in the mathernal forest stand on the control areas. In general, the sanitary condition of oak trees in all control sections was found to be worse compared to pine and hornbeam. The highest weakness coefficient was also established for oak trees in all experimental sections. The intensity of the processes of tree differentiation according to the sanitary condition was detected the highest on the control areas in the forest stands that have already over matured. On the other hand, the composition of xylotrophic macromycetes identified in hornbeam-pine-oak stands was found identical to those in pine-beech, pure beech and pine forest stands. At the same time, beech and pine trees in the pure forest stands have had worse sanitary health conditions than beech and pine trees in the mixed forests. The coefficient of tree differentiation intensity is higher in pure pine and beech stands than in mixed plantations. The pure beech stands have characterized the increased number of various pathologies and damages in comparison with mixed ones. Meanwhile, the number of trees with stem rot symptoms and fruiting bodies of wood decay fungi is higher in pure pines. The macromycetes related to the saprotrophic ecological group found on undamaged wood were predominant on the sites in all surveyed mixed stands. Fomes fomentarius, Laetiporus sulphureus, Ganoderma applanatum, Porodaedalea pini are parasitic macromycetes that can cause the great loss of technical quality of wood.

Keywords: hornbeam-pine-oak and pine-beech stands; aphyllophorales fungi; sanitary condition. 